\title{
Variable retention harvesting in the Douglas-fir region
}

\author{
Jerry F. Franklin ${ }^{1 *}$ (D) and Daniel C. Donato ${ }^{1,2}$
}

\begin{abstract}
Variable retention harvesting evolved in the Douglas-fir region of the Pacific Northwest gradually in response to increasing dissatisfaction with the ecological consequences of clear-cutting, from the standpoint of wildlife habitat and other important forest functions. It is a harvesting technique that can provide for retention (continuity) of such structures as large and old live trees, snags, and logs. Variable retention is based on the natural model of the biological legacies that are typically left behind following natural disturbances, such as wildfire, wind, and flood. Variable retention is also an important technique for fulfilling the first silvicultural principle of ecological forestry, that of providing for continuity in structure, function, and composition between forest generations. The history and current application of variable retention approaches on forests in western Washington and Oregon states (USA), where many of the fundamental concepts were first developed and applied, is described in this article.
\end{abstract}

Keywords: Biological legacies, Ecological forestry, Biodiversity conservation, Long-term sustainability, Washington and Oregon states

\section{Background}

The Douglas-fir region of the Pacific Coast of northwestern North America (west of the Cascade Range crest) is famous for its high productivity, dominance by evergreen conifers, and the massiveness of the older forest stands (Waring and Franklin 1979; Franklin and Dyrness 1988). A mild, wet climate provides favorable conditions for tree growth, but the massiveness of the forest is also due to the dominance of tree species that survive and continue to grow for centuries. Douglas-fir (Pseudotsuga menziesii) is arguably the keystone species in this forest and has been a mainstay of the wood products industry for decades. Western hemlock (Tsuga heterophylla) is its most common associate. Other coniferous species present in these forests include western redcedar (Thuja plicata), grand fir (Abies grandis), and western white pine (Pinus monticola). Sitka spruce (Picea sitchensis) is common close to the Pacific Ocean and Pacific silver fir (Abies amabilis) and noble fir (Abies procera) occur with Douglas-fir and western hemlock at higher elevations. Associated hardwoods commonly include bigleaf maple

\footnotetext{
* Correspondence: jff@uw.edu

${ }^{1}$ School of Environmental and Forest Science, College of the Environment,

University of Washington, Seattle, WA 98195, USA

Full list of author information is available at the end of the article
}

(Acer macrophyllum), red alder (Alnus rubra), black cottonwood (Populus trichocarpa), and Pacific madrone (Arbutus menziesii). Stand-originating forest disturbances in the Douglas-fir region are primarily wildfires that occurred at intervals of several centuries. However, windstorms are also important and provided the largest single historic disturbance. Old-growth forests (forests over 200 years of age and often much older) were dominant in the region when European settlers arrived in the mid-nineteenth century and provided most of the timber harvest through the mid-twentieth century.

\section{Adoption of clear-cutting on federal forestlands}

Early timber harvesting practices in the Douglas-fir region were predominantly clear-cutting. Retention of seed trees was an early regulatory requirement to try to ensure regeneration of commercial tree species. Prior to the Second World War, significant numbers of trees of less valuable species also were often left behind along with significant logging slash. In the late 1930s and early 1940 s, there was a significant debate over whether selection (uneven-aged) management would be a more desirable silvicultural practice than clear-cutting in Douglas-fir forests on national forests and other federal forest lands. A selection approach was favored by 
Regional Forester C. J. Buck. However, this proposal was strongly opposed by Thornton T. Munger and Leo Isaac, the Director and a leading silvicultural researcher, respectively, of the USDA Forest Service Pacific NW Forest and Range Experiment Station. Munger and Isaac ultimately won that debate, and the regional forester was given a directed transfer to Washington, DC, and clearcutting was continued.

The Forest Service timber management program developed rapidly following the Second World War as part of an effort to boost production of lumber and other wood products required to meet the needs of the booming post-war housing market. This effort was strongly encouraged by the White House and US Congress in the form of increased appropriations for roads and timber sale activities. It was the opportunity that many in the agency had dreamed of and planned for-the chance to dramatically expand access to previously remote timberlands and begin systematically converting natural forests to a regulated forest that would provide sustainable harvests and economically stable communities.

The national forests in the Douglas-fir region of western Oregon and Washington were a primary focus of this effort, because of the massive timber volumes present in the old-growth forests in these highly productive forest landscapes. The approach adopted was a specific landscape-level application of clear-cutting. It was called the staggered-setting system of clear-cutting and used primarily when initiating entries into totally virgin forest landscapes that dominated most of the federal forests (Franklin and Forman 1987). In this approach, the clear-cuts, which typically averaged between 40 and 60 acres, were dispersed along newly constructed roads, leaving the intervening natural forests unharvested during the initial entry. The skipped areas would then be removed in clear-cuts of similar size as part of subsequent harvest cycles.

The staggered-setting system of dispersed clear-cuts was adopted for several reasons, perhaps most importantly to accelerate the development of access to national forest lands as rapidly as possible. Roads were often constructed by the timber companies that bought timber sales, with road costs subsidized by the timber values being harvested; effectively, the road costs were typically subtracted from the receipts paid to the federal government for the stumpage. Other important reasons for dispersing moderate-sized clear-cuts included desires to prevent the creation of large contiguous areas of logging debris or slash and to obtain natural regeneration of trees through natural seeding from the adjacent green forest. Wildlife or biodiversity values were not a consideration although it was assumed that the clear-cuts with adjacent standing timber would be good habitat for ungulates, such as deer and elk.
By the late 1950s, the Forest Service decided that rapid natural regeneration of Douglas-fir and other desired species was not sufficiently dependable and adopted artificial regeneration by tree planting as its primary strategy for regeneration of commercial species. Developing dependable methods of growing, transporting, and planting nursery stock was a primary focus of research and development efforts in the 1960s, with success finally being largely achieved by the end of that decade except for environmentally severe (very hot or very cold) sites. High levels of harvested wood utilization were also sought (Fig. 1) and led to such practices as YUM (Yard Unmerchantable Material) and PUM (Pile Unmerchantable Material), in the hopes that such material would be utilized and levels of woody slash reduced on harvest areas and in streams.

\section{Increasing concerns with clear-cutting}

Concerns over the effects of clear-cutting on other resource values began to emerge in the 1970s, as clearcuts began to dominate federal forest landscapes in the Douglas-fir region. One of the emerging concerns was impacts on non-game wildlife, such as birds, small mammals, and amphibians. Many of these species required larger trees with decadent features, large dead trees (snags), and large logs on the forest floor. Snags were especially problematic because of their hazardous nature; safety regulations required the removal of any significant standing dead trees. Managers struggled to meet the need for wildlife trees and snags consistent with timber production and safety issues. Leaving such structures in areas undergoing harvesting was sometimes done, but they usually had to be left in unharvested patches. Creation of snags from green trees following completion of timber harvesting was another approach. This could be done in a variety of ways including topping green trees, killing green trees with post-harvest slash fires, or by simply leaving the trees and allowing natural processes to convert them to snags and logs.

The concept of leaving some green trees (as well as snags and logs, when possible) emerged from these efforts to provide wildlife structures and merged with other concerns that foresters were having. A common belief among foresters in the region was that any green trees left behind would soon blow down, which had been a common occurrence when cull (rotten) trees were left behind, as they had been in earlier decades. Forest researcher Roy Silen, on the other hand, showed that this was not necessarily the case; he had marked and harvested a shelterwood in an old-growth Douglas-fir forest on which there was no mortality after more than a decade (Franklin 1963). Also, in the 1970s, foresters had also become much more experienced in the use of shelterwood harvesting on environmentally severe sites. 


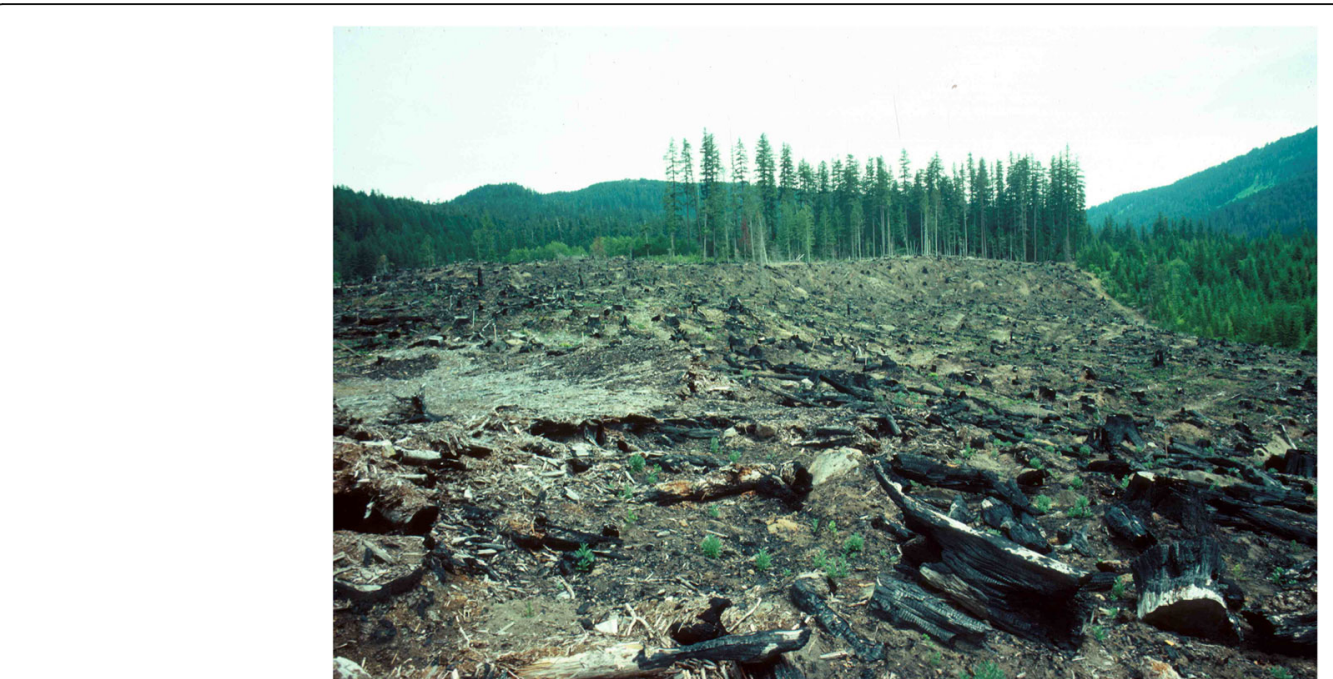

Fig. 1 Typical staggered-setting clear-cut in old-growth Douglas-fir forest on the Willamette National Forest (Oregon) in the late 1970s; note the high level of utilization and lack of significant slash after a broadcast burn of the site, which were considered to be evidence of good management

Hence, casual experimentation began with the purposeful retention of green trees on federal forestlands for wildlife as well as to achieve other ecological objectives. Some early trials were conducted on the H. J. Andrews and Wind River Experimental Forests (Fig. 2). These demonstrations involved retention of dominant and codominant Douglas-fir trees representing about 15\% of the pre-harvest live basal area. Leave trees were distributed uniformly over the harvest areas approximating a shelterwood overstory; however, the retained trees were to remain through the entire next rotation. Survival of the overstory trees and regeneration and growth of commercially important tree species was good over the next 35 years.

By the end of the 1970s, foresters were broadly experienced in conducting timber harvests in the Douglas-fir region with significant retention and survival of dominant and co-dominant green trees. These harvests were the first cut of a shelterwood system and not intended as permanent retention. The shelterwoods were needed to assure successful regeneration on environmentally severe sites, but they did help foresters and loggers develop the skills needed in harvesting while retaining a portion of the stand. Many of these shelterwoods actually became areas of permanent retention when the Northwest Forest Plan was adopted in 1994, before the planned removals of their overstories had been completed.

\section{Recognition of the natural model for retention}

On May 18, 1980, Mount St. Helens experienced a catastrophic eruption that created a large "devastated" region of $\sim 75,000$ ha, much of it located on the Gifford Pinchot National Forest in Washington. Many scientists

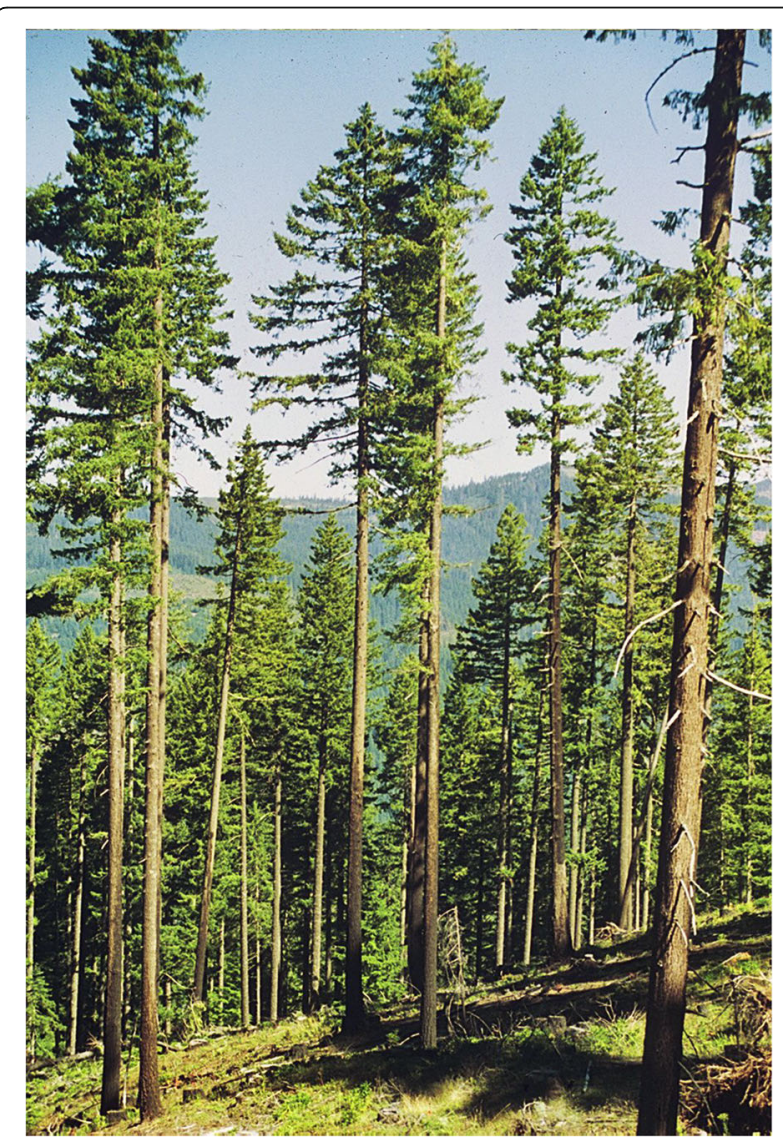

Fig. 2 The first retention harvest conducted by the senior author on the Willamette National Forest, Oregon; the prescription was for 15\% retention of live basal area in sound dominant and co-dominant mature Douglas-fir distributed uniformly over the harvested site. This selection of retained trees was done with the goal of both high levels of survival and availability of high-quality trees for harvest during the next harvest cycle 
and resource professionals initially likened the affected area to a moonscape in which most or all life had been extinguished; they hypothesized that reestablishment of biota would have to come primarily through longdistance dispersal of organisms from outside the blast zone. Subsequent research showed that many of the preeruption biota survived the eruption through various mechanisms and played very important roles in the post-eruption landscape (Dale et al. 2005). This included representatives of all pre-harvest tree species. In addition, vast amounts of dead organic materials remained following the eruption, much of it as fallen trees and snags (Fig. 3). These important surviving elements became known as biological legacies, the array of organisms, and organically derived structures and patterns that persist from the pre-disturbance landscape and which populate and influence the post-disturbance ecosystems (Franklin et al. 2000; Franklin et al. 2018). Legacies are, in effect, what distinguish secondary succession from primary succession.

The experiences at Mount St. Helens led researchers working there to review the conditions created by other natural forest disturbances, such as wildfire, wind, insects, floods, and avalanches (e.g., Foster et al. 1998). Such disturbances kill trees, but with only rare exceptions, leave behind immense legacies of dead organic materials (including logs and snags) as well as living legacies in diverse forms. Notably, each broad disturbance category (e.g., fire or wind) has a distinctive array of characteristic legacies. Of course, by design, classical clear-cutting leaves minimal legacies (Franklin et al. 2007). Biological legacies are the natural model on which variable retention harvesting and, more broadly, the first silvicultural principle of ecological forestry is based: "In ecological forestry silvicultural activities in forests, such as those associated with timber harvest, provide for significant continuity in forest structure, function, and composition between the pre- and post-harvest stand" (Franklin et al. 2018, p. 93).

\section{Evolution of the variable retention concept}

From the emergence of structural retention (live and dead) as a credible silvicultural concept in the Douglasfir region, its evolution was greatly influenced by several totally unrelated events.

\section{Plum Creek and Franklin's Epiphany}

The first event followed shortly after the senior author assumed a professorship at the University of Washington late in 1986. In 1987, the Plum Creek Timber Company contacted him with a request to provide company executives and foresters with suggestions about how they could modify their silvicultural practices, which mainly entailed clear-cutting. The company had been described as the "Darth Vader of the wood products industry" in the Wall Street Journal for their harvesting activities. They were interested in changing both the appearance and ecological impacts of their harvesting activities. After a morning of presentation and dialog on retention harvesting, Franklin left the group while executives and foresters met to discuss what they might do. Despite considerable skepticism, they decided that each management unit would undertake some trials of retention harvesting.

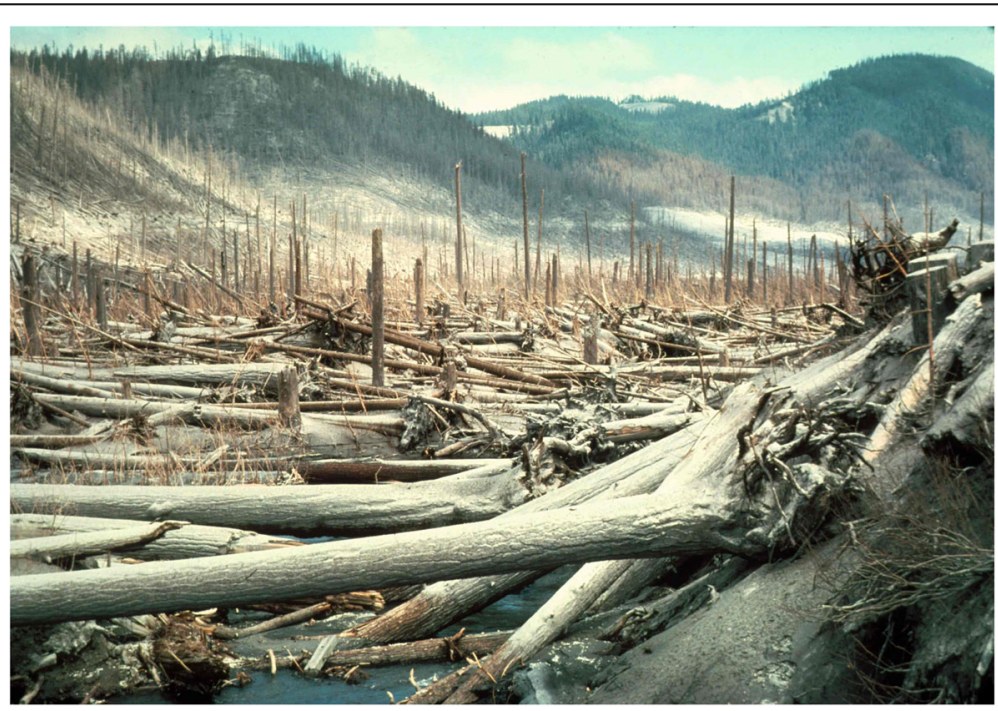

Fig. 3 The eruption of Mount St. Helens on May 18, 1980, left behind significant legacies of living and dead organic matter (including snags and logs), which were important elements in the development of the post-eruption ecosystems; this environment provided the stimulus for recognition of the concept of biological legacies of disturbances and a natural model for variable retention harvesting. Note that these legacies have both biological and physical influences on the post-disturbance ecosystem 
Plum Creek undertook a steep 4-month learning curve trying a variety of approaches (including several that were quite unsuccessful) until a break-through occurred with the Cougar Ramp harvest unit near Mount St. Helens. Plum Creek foresters at Cougar Ramp concentrated or, as it came to be called, aggregated all $15 \%$ of their retention in some patches and strips of intact forest (Fig. 4). This allowed them to retain structural elements of the harvested forest, such as soft snags, that they would not otherwise have been able to retain. It also freed up the harvested portion of the unit from retained structures, allowing cheaper and safer logging as well as aerial access for subsequent management activities. Franklin was asked to visit the site for his assessment of Cougar Ramp, which led him to finally recognize the merits of aggregating rather than dispersing retention. Up until this time, Franklin's view had been that retention generally needed to be dispersed across the harvest unit to be effective and, therefore, ecologically credible. Cougar Ramp provided an epiphany, recognition that there were significant ecological as well as operational benefits in aggregating retention. Subsequently, aggregated retention has received as much or more attention than dispersed retention in retention harvesting in the Pacific Northwest (Franklin et al. 1997).

\section{Congress mandates a retention experiment}

An appropriation subcommittee of the US House of Representatives contacted Drs. Logan Norris and Jerry Franklin in 1991 regarding their desire that the US Forest Service explore alternatives to clear-cutting for harvesting timber. The outcome was that Congress provided the US Forest Service with direction to initiate a large-scale study of diverse silvicultural strategies and funds to carry it out in their Fiscal Year 1993 appropriation. After considerable planning, review, and revision, the final design of this study was adopted in 1996 (Aubry et al. 2004). It was named the Demonstration of Ecosystem Management Options (DEMO), in part because some agency foresters opposed any reference to exploration of "alternatives to clear-cutting." As ultimately implemented, the DEMO experiment (Franklin et al. 1999) consists of six treatments that represent strongly contrasting levels (percentage of either the area or live basal area) and patterns (dispersed or aggregated) of green tree retention in a randomized complete block design. These are (1) 15\% dispersed retention, (2) 15\% aggregated retention (as 2 1-ha circles), (3) 40\% dispersed retention, (4) 40\% aggregated retention (as 5 1-ha circles), (5) $75 \%$ retention (harvest of 31 -ha circles), and (6) control (no harvest). Unfortunately, a clear-cut treatment was not included in the study because agency foresters objected that clear-cutting was no longer being done on national forests in the Douglas-fir region. Six replications of this experiment were established in 1997 and 1998 in mature and old Douglas-fir forest in Washington (4 replications) and Oregon (2 replications).

A wide variety of responses to the treatments have been studied following establishment including growth and mortality of the leave trees, tree regeneration, understory composition, mycorrhizal fungi, small mammals, breeding birds, canopy arthropods, bats, and amphibians. Measurements of some variables (primarily trees and other vegetation) are continuing. One key

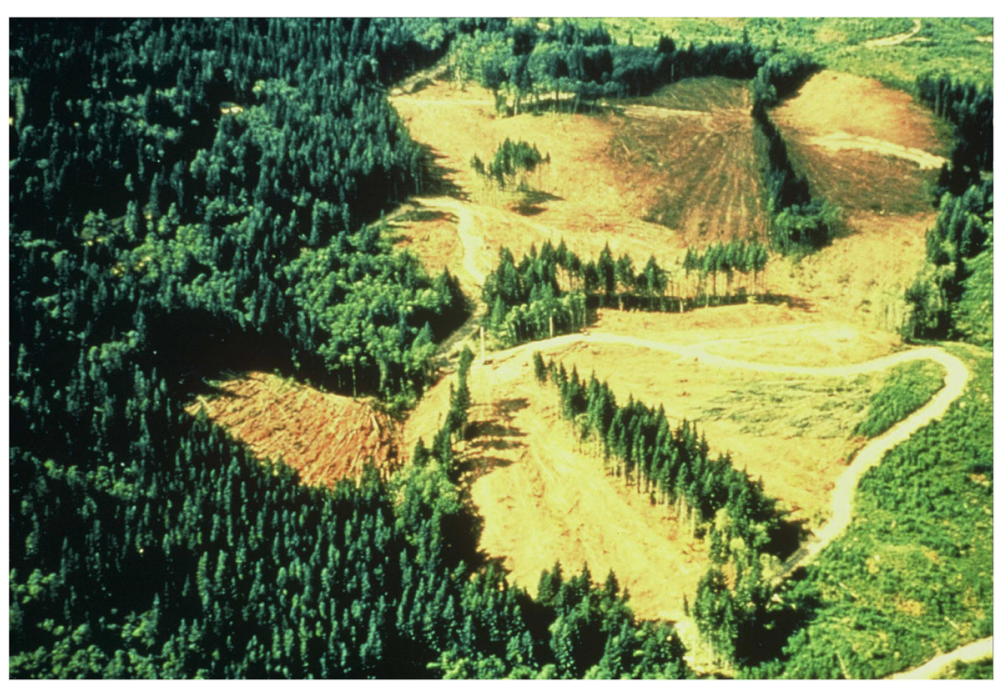

Fig. 4 After experimenting with different approaches to retention, the Plum Creek Timber Company found aggregated retention, as seen here on the Cougar Ramp Unit, was an effective approach to integrating environmental and timber management objectives. This cutting opened the senior author's mind to the potential of aggregated retention, which today is generally viewed as the most important approach for conserving a broad array of biota 
finding was that with larger (1 ha) aggregates and moderate levels of retention, variable retention harvesting can be implemented without risk of excessive mortality (Urgenson et al. 2013). The 1-ha aggregates created in the experiments provided refugia for understory vegetation but were susceptible to edge effects (Halpern et al. 2012). Additional results can be found in various publications as well as on the Web site of the Pacific Northwest Research Station (Portland, Oregon).

\section{Northwest Forest Plan mandates retention}

In 1994, the Northwest Forest Plan was adopted for federal forest lands within the range of the Northern Spotted Owl. This plan was developed at the direction of and with oversight by President Clinton, who had been elected in 1992. A federal court in Seattle, Washington, had ordered a halt to timber harvesting on federal forests in the Douglas-fir region in 1990, and candidate Clinton had promised to resolve the conflict as part of his 1992 presidential campaign. The major elements of the Northwest Forest Plan involved large changes in the land allocations for federal forestlands that resulted in commitment of about $80 \%$ of these lands to conservation objectives. Continued timber harvesting was allowed on portions of the remaining 20\% (the Matrix and Adaptive Management Area land allocations), but there was a requirement in the plan that any regeneration harvest would have to include at least $15 \%$ retention. On national forests, the stipulated retention was to be approximately $2 / 3$ aggregated retention and $1 / 3$ dispersed retention. On lands managed by the Bureau of Land Management, stipulated retention was as dispersed dominant and co-dominant trees; the reason for this direction is not clear-cut and proved to be disadvantageous from the standpoint of impacts on growth of tree regeneration on the harvested units.

\section{Variable retention labeled by the Clayoquot Sound Science Panel}

In 1993, the Prime Minister of the Province of British Columbia in Canada created a Scientific Panel for Sustainable Forest Practices in Clayoquot Sound (Clayoquot Sound Science Panel). The purpose of this panel was to advise the government regarding ecologically appropriate silvicultural practices on Crown Lands (a category of public land managed by the provinces) within the Clayoquot Sound region of Vancouver Island. This was part of a governmental response to major social disorders over the logging of old-growth forests in this region led by Native Americans (known in Canada as First Nations) and participated in by other Canadian citizens. The science panel conducted its activities and completed its report over the next year (Scientific Panel for Sustainable Forest Practices in Clayoquot Sound
1994). The Clayoquot Sound Science Panel recommended adoption of the "variable-retention silvicultural system" for all timber harvesting on Crown Lands in the region. The panel actually created the term "variable retention" to reflect the reality that the amount and other details of retention should vary depending upon management objectives and the nature of the stand being harvested. The panel recommended that harvests should "retain a minimum of $15 \%$ of the original stand on all cutting units ... [excepting] very small cutting units" and that the retention should "retain a representative crosssection of species and structures of the original stand." In areas with very high values for resources other than timber (such as wildlife habitat, slope stability), the panel recommended retention levels of at least $70 \%$. Hence, the Clayoquot Sound Science Panel contributed significantly to the concept as well as the name "variable retention." The panel's recommendations also helped set the stage for MacMillan-Bloedel Corporation's decision to replace clear-cutting with variable retention a few years later (Beese et al. 2019).

\section{Current applications of variable retention harvesting in the Pacific Northwest}

Variable-retention harvesting is now an accepted silvicultural concept in the Douglas-fir region as it is throughout most of the globe's temperate forest regions (Gustafsson et al. 2012; Franklin et al. 2018; Palik et al. n.d.). Applications typically include both dispersed and aggregated retention. In the following sections, we briefly review its use by the three major governmental organizations that manage large areas of forest lands in the region. On federal forestlands, there has been an emerging concern with creation of structurally complex early-successional ecosystems (those present following a stand-replacing disturbance but before tree canopy closure occurs), which represent the most biologically diverse stage in the forested landscapes of the Douglas-fir region. This developmental stage was not recognized as a major concern when retention harvesting was initiated in the region, but it is currently (e.g., Swanson et al. 2010; Olson and Van Horne 2017; Franklin and Johnson 2018). Hence, variable retention harvest applications on federal lands often are focused both on life-boating organisms and processes associated with closed forests and on providing the open conditions and structural legacies needed by early-successional organisms.

\section{US Bureau of Land Management (BLM)}

$\mathrm{BLM}$ is responsible for managing $\sim 1$ million hectares of federal forestland in western Oregon. Between 1994 and 2016, management direction was provided by the Northwest Forest Plan, which directed BLM to use variable retention in any regeneration harvesting 
that it conducted. BLM chose to meet that requirement using dispersed retention set at $15 \%$ of the live basal area; most retention was in the form of individual dominant and co-dominant trees. However, BLM is currently operating under a new plan, which it adopted in 2016 (US Bureau of Land Management 2016). BLM has been highly innovative in applying variable retention, recognizing the rich array of possibilities that it provides. It gained some early experience with a series of pilot projects (e.g., Fig. 5).

Variable retention is the approach used in all regeneration harvesting under the current BLM plan, with the nature of that retention varied depending upon the land allocation and the opportunities provided by the stand. There are two categories of land on which regeneration harvests occur: (1) the Moderate Intensity Timber Area (MITA) and the (2) Low Intensity Timber Area (LITA). On the MITA land allocation, which is mostly outside of Northern Spotted Owl Critical Habitat, 5 to $15 \%$ of the pre-harvest live basal area of the stand is retained after harvest. It is left in a variety of spatial patterns, including aggregated groups and individual trees. Silviculturalists are given wide latitude for creativity in implementation. Reforestation can be natural or artificial with the goal of obtaining an average of 375 trees per ha ${ }^{-1}$ within 5 years. Providing complex early successional habitat is an explicit goal following regeneration harvests.

On the LITA land allocation, which is mostly within Northern Spotted Owl Critical Habitat, 15 to 30\% of the pre-harvest live basal area of the stand is retained after regeneration harvest. Retention is provided as both aggregated groups and individual trees but, as with the MITA lands, silviculturalists are given wide latitude for creativity in implementation. Reforestation can be natural or artificial with the goal of establishing a stand average of 325 trees/ha within 5 years. Providing complex early successional habitat is an explicit goal following regeneration harvests. Selection management is used on the third land allocation, which is the Uneven-Aged Timber Area (UTA). This primarily consists of the Dry Forests found in southwestern Oregon. BLM also retains large and old trees on all land allocations, except where they must be removed for safety or operational considerations. In Dry Forests Douglas-fir and pine trees greater than or equal to $36 \mathrm{in.}$ DBH (diameter at breast height) and established prior to 1850 are retained along with hardwoods > 24 in. DBH. In Moist Forests, all trees greater than or equal $40 \mathrm{in}$. DBH and established prior to 1850 are retained.

\section{Washington Department of Natural Resources}

The Washington State Department of Natural Resources (WADNR) is among the most active implementers of variable retention harvesting in the Douglas-fir region. The WADNR manages well over 500,000 ha of forested land west of the Cascade Range crest, for diverse objectives including timber revenue, wildlife habitat, and public recreation. Most of these lands are managed under the state trust lands Habitat Conservation Plan (Washington Department of Natural Resources (WA

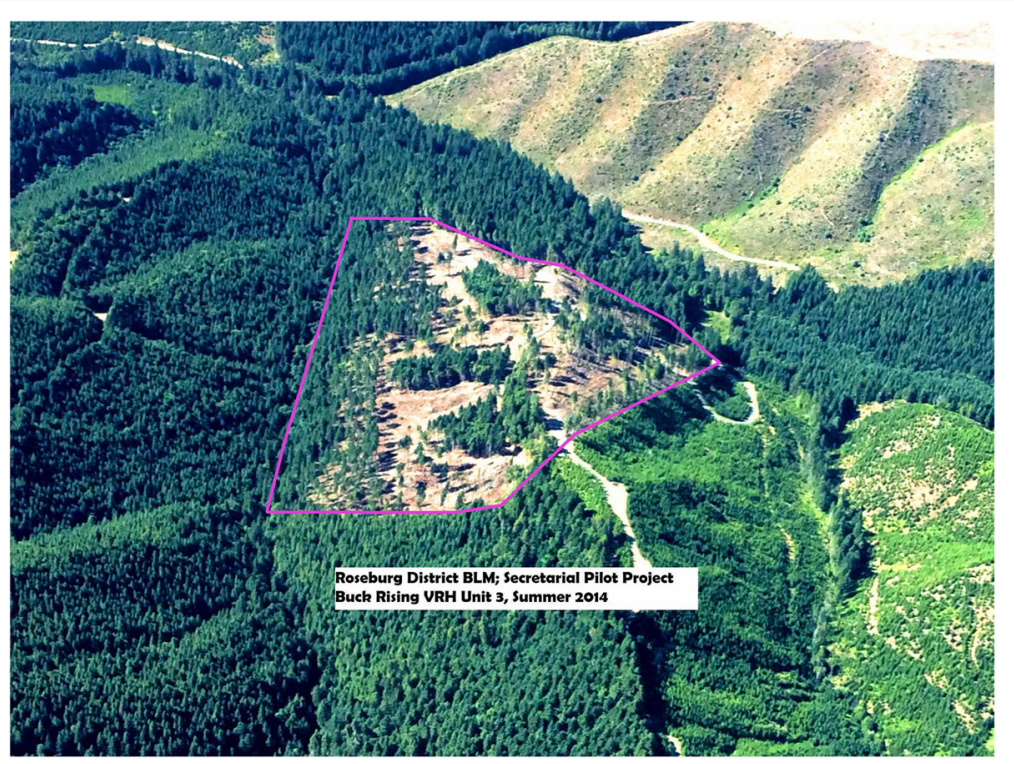

Fig. 5 The US Bureau of Land Management is making extensive use of innovative retention harvesting treatments in the management of $\sim 1$ million hectares of the forest in western Oregon; illustrated here is an aerial view of retention in a 50-year-old plantation. Note the lack of any kinds of legacies in the adjacent private forestlands (upper right of picture) that are managed for maximizing return-on-capital. All regeneration harvesting conducted by BLM on these lands is by variable-retention prescriptions 
DNR) 1997), a multi-species agreement with the US Fish \& Wildlife Service and NOAA Fisheries to provide habitat for threatened and endangered species often associated with older forests, including the northern spotted owl, marbled murrelet, and salmonids. Variable retention has been WADNR's primary silvicultural approach to regeneration harvests for the two decades since adoption of the Habitat Conservation Plan, which emphasizes retaining at least 20 trees per hectare ( 8 per acre), in a mix of dispersed and aggregated spatial patterns providing there are no major voids within timber units ( $<120 \mathrm{~m}$ between trees/aggregates). This retention occurs in addition to that in riparian buffers, unstable slopes, gene pool reserves, old-growth deferrals, and other conservation-driven allocations. The overall objective is to maintain and promote large structurally unique trees, snags, and down wood over time (Washington Department of Natural Resources (WA DNR) 1997).

Being one of the first major land bases to adopt variable retention at an operational scale, there has been some evolution in how the technique is implemented, but there are also some consistent themes. A key example of evolution over time has been a shift from dispersed retention in the early years following the Habitat Conservation Plan, to greater emphasis on aggregated retention (Fig. 6). Commonly, aggregated retention has proven more useful for protecting keystone or distinct ecological features that may not otherwise be protected by standard forest practice rules, such as seasonal seeps, small wetlands, unique microhabitats, and groves of exceptional trees. Variable retention has also provided opportunities for foresters to be creative in how retained trees are distributed, which characteristics are emphasized, and how prescriptions can be further tailored to individual site conditions.

The WADNR's implementation of variable retention also has had its challenges and uncertainties. One challenge has been meeting the intent to retain existing large snags during harvest operations. Safety concerns often must supersede this intent, and, in practical terms, significant snag retention occurs relatively rarely. The idea of clumping leave trees around important snags is often considered but the radius required to safely accommodate a large snag is often so large that it can effectively take up too much of the unit and/or the allotted number of leave trees for a unit. Finally, a key uncertainty is the fate of retention trees over one to multiple harvest cycles. Long-term effectiveness monitoring is needed to elucidate decadal rates of survival, and how these vary by abiotic (topographic setting, prevailing wind patterns, drought events) and biotic (clump size, species, size of leave tree) factors.

\section{United States Forest Service}

The United States Forest Service (USFS), which manages the national forests, currently is obliged to use variable retention harvesting within the area of the Northwest Forest Plan. At this point in time, almost all timber

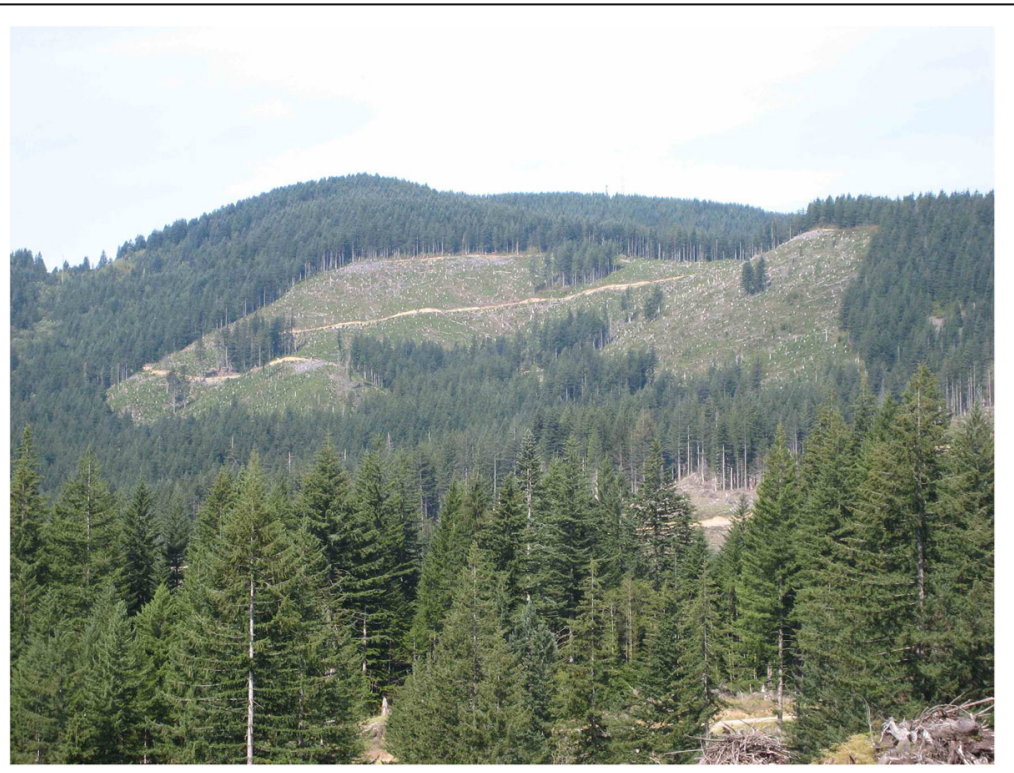

Fig. 6 Example of variable retention harvest as practiced across $>500,000$ ha of lands managed by the Washington State Department of Natural Resources. Variable retention has been the DNR's primary approach to regeneration harvests since the late 1990s, with an overall objective of maintaining and promoting large structurally unique trees, snags, and down wood over time. The minimum retention of 20 trees per hectare (mix of dispersed and aggregated pattern depending on individual unit) occurs in addition to that in riparian buffers, unstable slopes, gene pool reserves, old-growth deferrals, and other conservation-driven allocations 
harvesting that this agency is doing is either commercial thinning of plantations and other young forests and salvage logging in burned areas (Franklin and Johnson 2018). If or when programmed regeneration harvests are again undertaken, they are likely to be primarily in plantations and young stands previously harvested rather than remaining mature or old forest stands. Variable retention, including significant areas of large to medium aggregates and dispersed retention of individual and small clumps of green trees, snags, and logs on the harvested portions of management units, has been recommended if programmed regeneration harvests are resumed (Franklin and Johnson 2018). Under such an approach, the larger retained aggregates would include riparian buffers needed within the defined management or harvest unit. Franklin and Johnson (2018) suggest that approximately $1 / 3$ of the harvest unit should be in medium to large aggregates with an additional 5 to $10 \%$ retention as dispersed retention in the harvested portion of the unit.

\section{Conclusions}

Variable retention (VR) harvesting in the Douglas-fir region developed over several decades because traditional clear-cutting and even-aged silvicultural practices proved unable to adequately sustain important forest functions, including provision of habitat for biological diversity. Variable retention began on federal forestlands in the 1970s with low levels of live tree, snag, and $\log$ retention on harvest units that were otherwise cleared and gradually evolved into retention of modest numbers (e.g., 15\%) of uniformly distributed live trees on national forests. The concept of retaining trees and other structures as small forest patches, subsequently called aggregates, emerged from involvement with private landowners; the aggregated approach proved to have some operational and ecological advantages over dispersed retention in most silvicultural applications.

The 1980 eruption of Mount St. Helens greatly stimulated the conceptual development of the natural model that underpins variable retention harvesting. Despite the initial appearance of a moonscape appearance, most sites disturbed by this intense event had diverse and sometimes abundant surviving biota as well as abundant dead organic materials, including large wood structures. These persisting remnants of the pre-disturbance ecosystems were called biological legacies. Their presence at Mount St. Helens stimulated a broad scientific reassessment of the effects of natural disturbances on forests. Fire, wind, and outbreaks of insects and diseases were recognized to leave abundant live and dead biological legacies in their wake, which provide for continuity in structure, function, and composition between forest generations. Variable retention harvesting is now widely accepted and utilized on forest lands in the Douglas-fir region as a technique that can sustain environmental functions while still providing for economic returns from forest properties.

\begin{abstract}
Acknowledgements
This work has been supported by the Washington Department of Natural Resources and the School of Environmental and Forest Science at the University of Washington.
\end{abstract}

\section{Authors' contributions}

All the authors collaborate in equal participation to write the manuscript. Both authors read and approved the final manuscript.

\section{Funding}

Different projects from national and international calls between 1997 to date.

Availability of data and materials

At University of Washington repository.

Ethics approval and consent to participate

No ethics or conflict of interest exists.

Consent for publication

The authors consent to publish the data included in this draft.

Competing interests

The authors declare that they have no competing interests

\section{Author details}

'School of Environmental and Forest Science, College of the Environment, University of Washington, Seattle, WA 98195, USA. 'Washington Department of Natural Resources, Olympia, WA 98504, USA.

Received: 5 November 2019 Accepted: 19 November 2019

Published online: 20 January 2020

\section{References}

Aubry KB, Halpern CB, Maguire DA (2004) Ecological effects of variable-retention harvests in the northwestern United States: the DEMO study. For Snow Land Res 78(1/2):119-137

Beese WJ, Deal J, Dunsworth BG, Mitchell SJ, Philpot TJ (2019) Two decades of variable retention in British Columbia: an evaluation of its implementation and effectiveness for biodiversity conservation. Ecol Process 8:33

Dale VH, Swanson FJ, Crisafulli CM (2005) Ecological responses to the 1980 eruptions of Mount St. Helens. Springer, New York, USA, $342 \mathrm{p}$

Foster DR, Knight DH, Franklin JF (1998) Landscape patterns and legacies resulting from large, infrequent forest disturbances. Ecosystems 1:497-510

Franklin JF (1963) Natural regeneration of Douglas-fir and associated species using modified clear-cutting systems in the Oregon Cascades. USDA Forest Service Research Paper PNW 3, 14 p.

Franklin JF, Berg DE, Thornburgh DA, Tappeiner JC (1997) Alternative silvicultural approaches to timber harvest: variable retention harvest systems. In: Creating a forestry for the $21^{\text {st }}$ Century (Kohm KA, Franklin JF, Eds). Island Press, Washington DC, USA, pp 111-139

Franklin JF, Dyrness CT (1988) Natural vegetation of Oregon and Washington. Oregon State University Press, Corvallis, USA.

Franklin JF, Johnson KN (2018) The 2012 Planning rule and ecological integrity: maintaining and restoring the National Forests of the Douglas-fir Region. In: 193 Million Acres: Toward a healthier and more resilient US Forest Service (Wilent S, Ed). Pp 487-520. Society of American Foresters, Bethesda, MD, USA

Franklin JF, Johnson KN, Johnson DL (2018) Ecological forest management. Waveland Press, Long Grove, USA, p 646

Franklin JF, Lindenmayer D, MacMahon JA, McKee A, Magnuson J, Perry DA, Waide R, Foster D (2000) Threads of continuity. Conserv Biol in Practice 1(1):9-16

Franklin JF, Mitchell RJ, Palik BJ (2007) Natural disturbance and stand development principles for ecological forestry. USDA Forest Service Northern Research Station General Technical Report NRS-19. Newton Square, PA, USA. 
Franklin JF, Norris LA, Berg DR, Smith GR (1999) The history of an experiment in regeneration harvest of northwestern forest ecosystems. Northwest Sci 73:3-11

Gustafsson L, Baker S, Bauhus J, Beese W, Brodie A, Kouki J, Lindenmayer D, Löhmus A, Martínez Pastur G, Messier C, Neyland M, Palik B, SverdrupThygeson A, Volney J, Wayne A, Franklin J (2012) Retention forestry to maintain multifunctional forests: a world perspective. Bioscience 62(7): 633-645

Halpern CB, Halaj J, Evans SA, Dovciak M (2012) Level and pattern of overstory retention interact to shape long-term responses of understories to timber harvest. Ecol Appl 22(8):2049-2064

Olson DH, Van Horne B (2017) People, forests, and change: lessons from the Pacific Northwest. Island Press, Washington DC, USA, 331 p

Palik B, D'Amato A, Franklin J, Johnson KN (In press) Ecological silviculture. In: Foundations and Applications. Waveland Press, Long Grove, IL, USA

Scientific Panel for Sustainable Forest Practices in Clayoquot Sound (1994) Sustainable ecosystem management in Clayoquot Sound. Planning and practices. Cortex Consultants Inc., Victoria, BC, Canada, p 296

Swanson ME, Franklin JF, Beschta RL, Crisafulli CM, DellaSalla DA, Hutto RL, Lindenmayer DB, Swanson FJ (2010) The forgotten stage of forest succession: early successional ecosystems on forest sites. Front Ecol Environ 9(2):117-125

Urgenson LS, Halpern CB, Anderson PD (2013) Level and pattern of overstory retention influence rates and forms of tree mortality in mature, coniferous forests of the Pacific Northwest, USA. For Ecol Manage 108:116-127

US Bureau of Land Management (2016) Northwestern and Coastal Oregon record of decision and approved Resource Management Plan. Available at www.tinyurl.com/yakslgyj (last accessed: 6/26/18).

Waring RH, Franklin JF (1979). Evergreen coniferous forests of the Pacific Northwest. Science 204: 1380-1386.

\section{Publisher's Note}

Springer Nature remains neutral with regard to jurisdictional claims in published maps and institutional affiliations.

\section{Submit your manuscript to a SpringerOpen ${ }^{\circ}$ journal and benefit from:}

- Convenient online submission

- Rigorous peer review

- Open access: articles freely available online

High visibility within the field

- Retaining the copyright to your article

Submit your next manuscript at $\boldsymbol{\nabla}$ springeropen.com 